\title{
Interpretation of Isotherm Models for Adsorption of Ammonium onto Granular Activated Carbon
}

\author{
Nur Atikah Abdul Salim 1,*(iD), Mohd Hafiz Puteh 1,2*, Mohd Hairul Khamidun ${ }^{3}$, \\ Mohamad Ali Fulazzaky ${ }^{4}$, Noorul Hudai Abdullah ${ }^{5}$, Abdull Rahim Mohd Yusoff ${ }^{6}$, Muhammad Abbas \\ Ahmad Zaini ${ }^{7}$, Noraziah Ahmad ${ }^{1}$, Zainab Mat Lazim ${ }^{1}$, Maria Nuid ${ }^{1}$ \\ 1 School of Civil Engineering, Faculty of Engineering, Universiti Teknologi Malaysia, 81310 UTM Johor, Malaysia \\ 2 Centre for Environmental Sustainability and Water Security, Research Institute for Sustainable Environment, Universiti \\ Teknologi Malaysia, 81310 UTM Johor, Malaysia \\ 3 Faculty of Civil and Environmental Engineering, Universiti Tun Hussein Onn Malaysia, 86400 UTHM, Johor, Malaysia \\ 4 Department of Postgraduate Studies, Djuanda University, 16720 Bogor, Indonesia \\ 5 Centre For Diploma Studies, Faculty of Civil Engineering, Universiti Tun Hussein Onn Malaysia, 84600 UTHM, Johor, \\ Malaysia \\ 6 Faculty of Science, Universiti Teknologi Malaysia, 81310 UTM Johor, Malaysia \\ 7 School of Chemical and Energy Engineering, Faculty of Engineering, Universiti Teknologi Malaysia, 81310 UTM Johor, \\ Malaysia \\ * Correspondence: atikahsalim@gmail.com or natikah57@live.utm.my; mhafizputeh@utm.my
}

Scopus Author ID 56196515400

Received: 4.08.2020; Revised: 6.09.2020; Accepted: 7.09.2020; Published: 10.09.2020

\begin{abstract}
High amounts of ammonium $\left(\mathrm{NH}_{4}^{+}\right)$discharged in receiving water can lead to eutrophication. The adsorption of $\mathrm{NH}_{4}{ }^{+}$from synthetic solution onto granular activated carbon (GAC) was scrutinized with respect to initial solute concentration $\left(10 \mathrm{mg} \mathrm{L}^{-1}\right)$, solution volume $(0.2 \mathrm{~L})$, adsorbent dosage $(4-$ $20 \mathrm{~g}$ ), and contact time. Experimental data can be well described by the pseudo-second-order kinetic model $\left(R^{2}>0.994\right)$ and Freundlich isotherm model $\left(R^{2}=0.936\right)$, suggesting that chemisorption and multilayer adsorption occurred. Furthermore, this study explored the feasibility of using the Freundlich isotherm model to estimate the removal efficiency or required amount of adsorbent. The result findings indicated that GAC has a good potential to adsorb $\mathrm{NH}_{4}{ }^{+}$from water and thus giving new insights into environmental engineering practices.
\end{abstract}

Keywords: adsorption; ammonium; eutrophication; isotherm model; granular activated carbon.

(C) 2020 by the authors. This article is an open-access article distributed under the terms and conditions of the Creative Commons Attribution (CC BY) license (https://creativecommons.org/licenses/by/4.0/).

\section{Introduction}

Nitrogenous matters such as ammonium, nitrite, and nitrate are an important element for animals and plants. However, the discharge of excessive amounts of these matters into surface water strongly accelerates eutrophication [1,2]. Over enrichment of nitrogenous matters in the water, body expedites the plant growth and causing algal bloom. The water body may also lose its important functions and subsequently cause negative effects on the environment and human health $[3,4]$. The effects of the release of nitrogen to surface water have led to legislations such as those by the United States Environmental Protection Agency (USEPA) and the European Union (EU) [5]. The USEPA permits the effluent limit of nitrogen must be less than $10 \mathrm{mg} \mathrm{L}^{-1}$, while the EU only allows $15 \mathrm{mg} \mathrm{L}^{-1}$ of nitrogen for $10,000-$ 100,000 population equivalents.

The excessive amounts of nitrogen can be treated with plenty of methods such as adsorption technique, biological nitrogen process, chemical process, and nanotechnology 
application [6-9]. The biological process to treat wastewater can be highly variable due to operational difficulties, while the nanotechnology application and chemical treatment entail high chemical costs $[10,11]$. From all these removal methods, adsorption is considered as a promising technique that could be employed in the removal of nitrogen from the water, given its simple operation and low-cost of the adsorbent materials [1, 12]. Nowadays, the use of GAC as an economic adsorbent for treating water has received extensive attention because of its potential in environmental and agronomic applications [13]. GAC can adsorb various pollutants due to high porous structure and high specific surface area. GAC has been used for the removal of specific chemicals such as potassium and phosphorus, which ultimately can be converted to fertilizer [14]. Moreover, GAC could also be used to remove nitrogen from water $[15,16]$.

Considering that the presence of algae in the water, with its chemical formula of $\left(\mathrm{CH}_{2} \mathrm{O}\right)_{106}\left(\mathrm{NH}_{3}\right)_{16}\left(\mathrm{H}_{3} \mathrm{PO}_{4}\right)$, resulting in eutrophication consists of ammonium $\left(\mathrm{NH}_{4}{ }^{+}\right)$[17], eutrophication can be controlled effectively by the removal of $\mathrm{NH}_{4}^{+}$. Hence, the aim of this study was to examine the feasibility of utilizing GAC for $\mathrm{NH}_{4}{ }^{+}$removal from synthetic solutions with respect to adsorbent dosage $(m)$, solute concentration $\left(C_{\mathrm{i}}\right)$, and contact time $(t)$. The Freundlich and Langmuir isotherm models were employed to understand the mechanism of adsorption. Furthermore, this work aimed to elucidate how basic adsorption isotherm (i.e., Freundlich isotherm model) combined with material balance can be used to predict the value of $m$ or removal efficiency $(E)$ according to a given set of initial conditions. This work was performed to have an enabling methodology for the development of a computational model that can be used to make engineering predictions with quantified confidence. Besides that, it could be ideally applied to industrial applications.

\section{Materials and Methods}

\subsection{Adsorption kinetics and isotherms.}

\subsubsection{Kinetic adsorption models.}

Pseudo-first-order (PFO) and pseudo-second-order (PSO) kinetic models were used for describing the adsorption mechanism (Table 1). PFO equation can be expressed as given in Eq. (1) $[15]:$

$$
\ln \left(q_{e}-q_{t}\right)=\ln \left(q_{e}\right)-k_{1} t_{i}
$$

PSO equation can be expressed as [16]:

$$
\frac{t_{i}}{q_{t}}=\frac{1}{k_{2} q_{e}^{2}}+\frac{t_{i}}{q_{e}}
$$

Eq. (1) can be used to determine the value of $k_{1}$ if the value of $q_{\mathrm{e}}$ has been verified through an experiment when its equilibrium adsorption is reached. The adsorption kinetic obeys a PFO model when the curve of plotting $\ln \left(q_{\mathrm{e}}-q_{\mathrm{t}}\right)$ against $t_{\mathrm{i}}$ gives a linear relationship depending on the adsorbate in aqueous solution [16].

A plot of $t_{\mathrm{i}} / q_{\mathrm{t}}$ against $t_{\mathrm{i}}$ of the Eq. (2) should give a linear relationship with $1 / q_{\mathrm{e}}$ as slope and $1 / k_{2} q_{\mathrm{e}}{ }^{2}$ intercept at the vertical axis. The value of $k_{2}$ is a constant depending on the adsorbate with influence another parameter when the experimental adsorption kinetics data obey the PSO model [16]. 
Table 1. List of kinetic and isotherm adsorption models.

\begin{tabular}{|c|c|c|c|}
\hline Models & Linear form & Plot & Parameters \\
\hline \multicolumn{4}{|l|}{ Kinetic } \\
\hline PFO & $\ln \left(q_{e}-q_{t}\right)=\ln \left(q_{e}\right)-k_{1} t_{i}$ & $\ln \left(q_{\mathrm{e}}-q_{\mathrm{t}}\right)$ vs. $t_{\mathrm{i}}$ & $\begin{array}{l}q_{\mathrm{e}} \\
k_{1}\end{array}$ \\
\hline PSO & $\frac{t_{i}}{q_{t}}=\frac{1}{k_{2} q_{e}^{2}}+\frac{t_{i}}{q_{e}}$ & $\frac{t_{i}}{q_{t}}$ vs. $t_{i}$ & $\begin{array}{l}q_{\mathrm{e}} \\
k_{2}\end{array}$ \\
\hline \multicolumn{4}{|l|}{ Isotherm } \\
\hline Freundlich & $\ln q_{e}=\ln K_{F}+\frac{1}{n} \ln C_{e}$ & $\ln q_{\mathrm{e}} v s . \ln C_{\mathrm{e}}$ & $\begin{array}{l}K_{\mathrm{F}} \\
n\end{array}$ \\
\hline Langmuir & $\frac{1}{q_{e}}=\frac{1}{K_{L} q_{\max } C_{e}}+\frac{1}{q_{\max }}$ & $\frac{1}{q_{e}} v s \cdot \frac{1}{C_{e}}$ & $\begin{array}{l}q_{\max } \\
K_{\mathrm{L}} \\
\end{array}$ \\
\hline $\begin{array}{l}\text { Nomenclature } \\
k_{1} \\
k_{2} \\
K_{\mathrm{F}} \\
K_{\mathrm{L}} \\
n \\
C_{\mathrm{e}} \\
q_{\mathrm{e}} \\
q_{\mathrm{t}} \\
q_{\max } \\
t \mathrm{i}\end{array}$ & $\begin{array}{l}\text { PFO constant }\left(\mathrm{min}^{-1}\right) \\
\text { PFO constant }\left(\mathrm{g} \mathrm{mg}^{-1} \mathrm{~min}^{-1}\right) \\
\text { Freundlich constant }\left(\mathrm{mg} \mathrm{g}^{-1}\right) \\
\text { adsorption energy coefficient }\left(\mathrm{L} \mathrm{mg}^{-1}\right) \\
\text { heterogeneity factor (dimensionless) } \\
\text { concentration of the adsorbate at equilibrium }\left(\mathrm{mg} \mathrm{L}^{-1}\right) \\
\text { adsorption capacity at equilibrium }\left(\mathrm{mg} \mathrm{g}^{-1}\right) \\
\text { adsorption capacity at time } t\left(\mathrm{mg} \mathrm{g}^{-1}\right) \\
\text { maximum adsorption capacity }\left(\mathrm{mg} \mathrm{g}^{-1}\right) \\
\text { adsorption time (min) }\end{array}$ & & \\
\hline
\end{tabular}

2.1.2. Isotherm adsorption models.

The Freundlich and Langmuir equations are the equations commonly used to describe adsorption isotherms (Table 1). The Freundlich model describes that the heterogeneous surface of the adsorbates is formed on the surface of adsorbent with multilayer sorption of different energies of adsorption [18]. The Langmuir model assumes that the adsorbent is being saturated when the monolayer adsorbate coverage of adsorbent is attached with a homogenous surface without interactions between the adsorbed molecules [19]. The Freundlich equation can be written as [20]:

$$
\ln q_{e}=\ln K_{F}+\frac{1}{n} \ln C_{e}
$$

The Langmuir equation can be expressed as [16]:

$$
\frac{1}{q_{e}}=\frac{1}{K_{L} q_{\max } C_{e}}+\frac{1}{q_{\max }}
$$

The Freundlich isotherm suggests that a plot $\ln q_{\mathrm{e}}$ against $\ln C_{\mathrm{e}}$ of the Eq. (3) should give a straight-line intercept at $K_{\mathrm{F}}$ with $1 / n$ as the slope. The adsorption coefficient $K_{\mathrm{F}}$ may indicate the affinity of adsorbate-adsorbent. The exponent $n$ is related to the energetic heterogeneity of the adsorbent surface and determines either the favorable or unfavorable curve [21]. A plot of $1 / q_{\mathrm{e}}$ versus $1 / C_{\mathrm{e}}$ of Eq. (4) should give a straight line with $1 / K_{\mathrm{L}} q_{\max }$ and $1 / \mathrm{q}_{\max }$ as the slope and the intercept, respectively.

2.1.3. Freundlich isotherm model development.

The Freundlich isotherm can be expressed as [22]:

$$
q_{e}=K_{F} C_{e}^{1 / n}
$$

The value of $C_{\mathrm{e}}$ and $q_{\mathrm{e}}$ can be calculated for a series of different conditions. Then $\ln q_{\mathrm{e}}$ can be plotted as a function of $\ln C_{\mathrm{e}}$. The adsorption isotherm obeys a Freundlich model when the curve of plotting $\ln q_{\mathrm{e}}$ against $\ln C_{\mathrm{e}}$ of Eq. (3) gives a straight line. Therefore, the values of $1 / n$ and $K_{\mathrm{F}}$ can be determined from the slope and the intercept of Eq. (3).

The $q_{\mathrm{e}}$ in Eq. (5) can also be written as [22]: 


$$
q_{e}=\left(\frac{V C_{e}^{S}}{m}\right)
$$

The isotherm equation was combined with a material balance [22]. In a batch study, the mass balance expression should be obeyed by the following expression:

$$
C_{i}=C_{e}+C_{e}^{S}
$$

where $C_{\mathrm{i}}$ and $C_{e}^{S}$ are the solute concentration at the initial and the equilibrium, respectively. The $q_{\mathrm{e}}$ in Eq. (6) can also be written by the following equation [22]:

$$
q_{e}=\left(\frac{V C_{e}^{S}}{m}\right)=\frac{V\left(C_{i}-C_{e}\right)}{m}
$$

The Freundlich isotherm was rearranged with mass balance. Substituting Eq. (8) into Eq. (5) gives

$$
\frac{K_{F} m}{V} C_{e}^{1 / n}+C_{e}-C_{i}=0
$$

in which $C_{\mathrm{e}}$ is a one-argument variable as follows. Even though Eq. (9) is not an explicit one and should be solved by using the numerical analysis method, $C_{\mathrm{e}}$ is a function of $C_{\mathrm{i}}$ and $m$ for a specific $V$ with parameters $K_{\mathrm{F}}$ and $1 / n$. Therefore, with Eq. (10), $E=E\left(C_{\mathrm{i}}, m\right)$.

Furthermore, $E$ can be expressed as:

$$
E=\frac{C_{i}-C_{e}}{C_{i}}
$$

Substituting Eqs. (8) and (10) into Eq. (5), giving:

$$
m=\frac{V}{K_{F}} \frac{E}{(1-E)^{1 / n}} C_{i}^{(1-1 / n)}
$$

where $m=m\left(C_{\mathrm{i}}, E\right)$ for a fixed $V$ as shown in (Figure 1). Note that, Eq. (11) can be used to calculate the value of $m$ for the desired value of $E$.

Therefore, when predicted $m$ and $E$ are obtained, adsorption $q$ predicted can be estimated by substituting Eq. (10) into Eq. (8), giving:

$$
q=\frac{E C_{i} V}{m}
$$

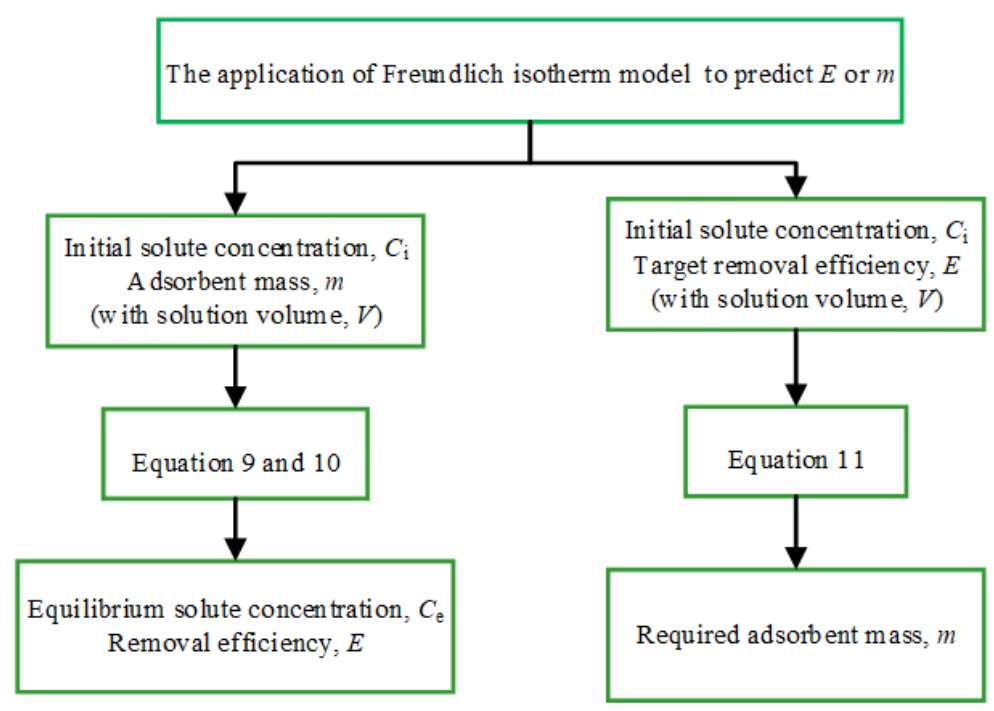

Figure 1. Diagram for the application of the Freundlich isotherm model for the estimation of $E$ and $m$.

2.1.4. Freundlich isotherm parameter evaluation and model calculation.

The experimental data for $\mathrm{NH}_{4}{ }^{+}$adsorption was fitted to the Freundlich model in Eq. (3) to evaluate isotherm parameters. The Newton-Raphson method [22] was applied to solve Eq. (9). The application tool for users was created using Excel to predict the value of $E$ or $m$. 


\section{Results and Discussion}

\subsection{Adsorbents.}

The commercial GAC was used as an adsorbent in this study. The GAC was purchased from Nikom Global Marketing (M) Sdn. Bhd., Selangor, Malaysia, and the raw material required to produce commercial GAC was coconut shell charcoal. Table 2 shows the characteristics of the GAC. The sample was washed several times with tap water. Next, the cleaned sample was oven-dried for $48 \mathrm{~h}$ at $30^{\circ} \mathrm{C}$. The sample was crushed and then sieved to $0.60 \mathrm{~mm}$.

Table 2. Main characteristics of the granular activated carbon.

\begin{tabular}{l|l|l} 
Characteristic & Unit & Value \\
\hline Origin (raw material) & & Coconut shell \\
\hline Bulk density & $\mathrm{g} \mathrm{cm}^{-3}$ & $0.52-0.54$ \\
\hline Moisture contents & $\%$ & 5 \\
\hline Hardness & $\%$ & $97-98$ \\
\hline Ash content & $\%$ & 5 \\
\hline BET surface area & $\mathrm{m}^{2} \mathrm{~g}^{-1}$ & 1100 \\
\hline $\mathrm{pH}$ & & $9-10$
\end{tabular}

\subsection{Synthetic solutions.}

Synthetic solution $\left(\mathrm{NH}_{4}{ }^{+}, 10 \mathrm{mg} \mathrm{L}{ }^{-1}\right)$ was prepared by dissolving ammonium chloride $\left(\mathrm{NH}_{4} \mathrm{Cl}\right)$ (analytic grade) into deionized water.

\subsection{Analytical methods.}

$\mathrm{NH}_{4}{ }^{+}$was determined using the Nessler method (HACH DR 6000, Spectrophotometer) [23]. Instrumental analysis was used to identify the characteristics of the GAC. In this work, the GAC samples were previously sputter-coated with gold (Sputter Coater, Model SC7620, Quorum Technologies, UK). A scanning electron microscope (SEM) (Model TM3000, Hitachi, Japan) was used to characterize the surface morphology of the unmodified GAC. The mineral phases in the GAC can be identified using a Bruker D8 advance high-resolution X-Ray Diffractometer (XRD). The chemical composition (in \%) of GAC was analyzed using Energy Dispersive X-Ray Fluorescence (EDXRF) Spectrometer (Rigaku, Japan). The functional groups of the GAC were investigated using Fourier Transform Infrared (FTIR) Spectroscopy (IRTracer-100, Shimadzu, Japan). The surface area of GAC was performed by a multiple-point method according to the Brunauer, Emmett, and Teller (BET) theory, using a surfer analyzer (Surface Analyzer, Thermo Scientific Technologies, Italy).

\subsection{Boehm titration.}

The Boehm titration method was applied to determine the surface functional groups of GAC [24], where $0.3 \mathrm{~g}$ of GAC was added to $15 \mathrm{~mL}$ of sodium hydroxide $(\mathrm{NaOH})(0.1 \mathrm{M})$, sodium carbonate $\left(\mathrm{Na}_{2} \mathrm{CO}_{3}\right)(0.05 \mathrm{M})$, sodium hydrogen carbonate $\left(\mathrm{NaHCO}_{3}\right)(0.1 \mathrm{M})$ or hydrochloric acid $(\mathrm{HCl})(0.1 \mathrm{M})$ solution in the flask, separately. The blanks and the sample solutions were shaken at a speed of $100 \mathrm{rpm}$ and $25^{\circ} \mathrm{C}$ for $48 \mathrm{~h}$. Then, $5 \mathrm{~mL}$ aliquots of each sample were filtered, and the excess of acid and bases was back-titrated with $\mathrm{NaOH}(0.1 \mathrm{M})$ and $\mathrm{HCl}(0.05 \mathrm{M})$, respectively. The number of basic surface functional groups was determined on the assumptions that $\mathrm{HCl}$ neutralized basic groups while the number of acidic surfaces functional groups were identified on the assumptions that $\mathrm{NaHCO}_{3}$ neutralized only carboxylic 
groups, $\mathrm{Na}_{2} \mathrm{CO}_{3}$ neutralized lactonic and carboxylic groups, and $\mathrm{NaOH}$ neutralized phenolic, lactonic and carboxylic groups [24].

\subsection{Batch experiments.}

The adsorption isotherm and kinetics were determined through batch experiments. The kinetic experiments were performed by adding 4, 12, and $20 \mathrm{~g}$ of the adsorbent, and the isotherm experiments were performed by adding 4, 8, 12, 16, and $20 \mathrm{~g}$ of the adsorbent into a different flask containing $0.2 \mathrm{~L}$ of $10 \mathrm{mg} \mathrm{L}^{-1}$ synthetic solution. Each sample solution was shaken at $160 \mathrm{rpm}$, and then the concentrations of $\mathrm{NH}_{4}{ }^{+}$in each flask were identified at certain time intervals. The sample solutions were centrifuged, and the HACH DR $6000 \mathrm{UV}-\mathrm{Vis}$ Spectrophotometer was used to evaluate supernatant concentrations of $\mathrm{NH}_{4}{ }^{+}$present in each Erlenmeyer flask. The adsorption mechanism was determined by using the PFO, PSO, Langmuir, and Freundlich models. Each batch adsorption experiment was conducted twice, and the data obtained are the average values. The adsorption capacity $(q)$ and the $E$ were calculated using Eq. (8) and Eq. (10), respectively.

\subsection{Physicochemical characteristics of GAC.}

The surface functional groups of GAC were identified according to the Boehm titration method (Figure 2). The GAC consists of total acidic functional group (TAFG) and total basic functional group (TBFG) with the amounts of 1.35 and $1.03 \mathrm{mmol} \mathrm{g}^{-1}$, respectively (Figure 2). The TAFG comprises carboxylic, lactonic, and phenolic groups with the amounts of $0.70,0.50$, and $0.15 \mathrm{mmol} \mathrm{g}^{-1}$, respectively. The TAFG $\left(1.35 \mathrm{mmol} \mathrm{g}^{-1}\right)$ of higher than the TBFG (1.03 mmol $\mathrm{g}^{-1}$ ) was evaluated and could have more ability to adsorb more $\mathrm{NH}_{4}{ }^{+}$ions from the solution. In addition, the studied GAC has a BET surface area of $1100 \mathrm{~m}^{2} \mathrm{~g}^{-1}$ (Table 2).

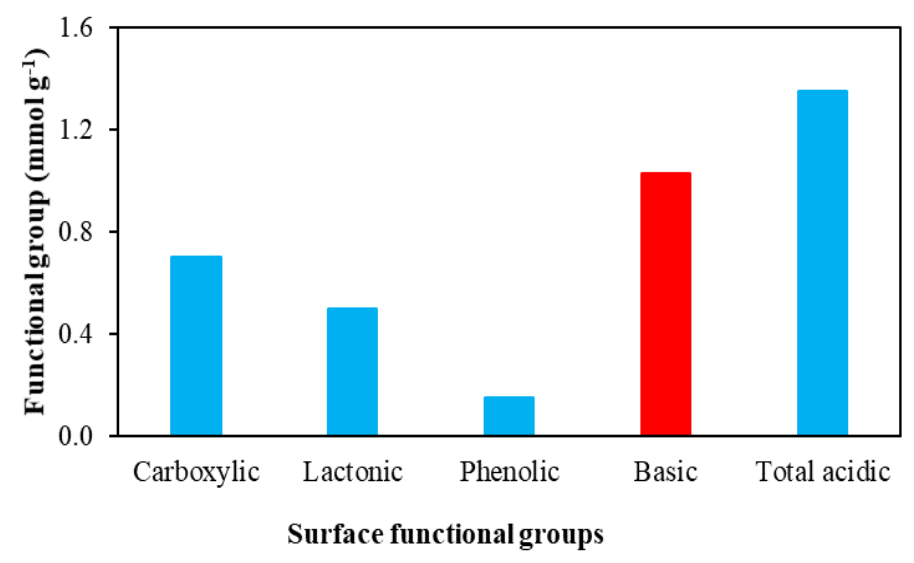

Figure 2. The surface functional groups of GAC.

The images from the SEM micrograph with 500, 2500, and 5000 times magnification were used to identify the surface morphology of the GAC (Figure 3). The surface feature of GAC has a coarse porous surface with irregular pores (Figure 3a). The images from the SEM micrograph with 2500 and 5000 times magnification has a rough texture with various pore size at the surface of the GAC (Figure $3 \mathrm{~b}$ and Figure 3c).

The XRD pattern of the GAC is illustrated in Figure 4. The broad peaks $2 \theta$ of $26^{\circ}$ and $2 \theta$ of $43^{\circ}$ denote the graphitic structure [25]. The sharp peak at $2 \theta$ of $76^{\circ}$ represents the quartz $\left(\mathrm{SiO}_{2}\right)$. 

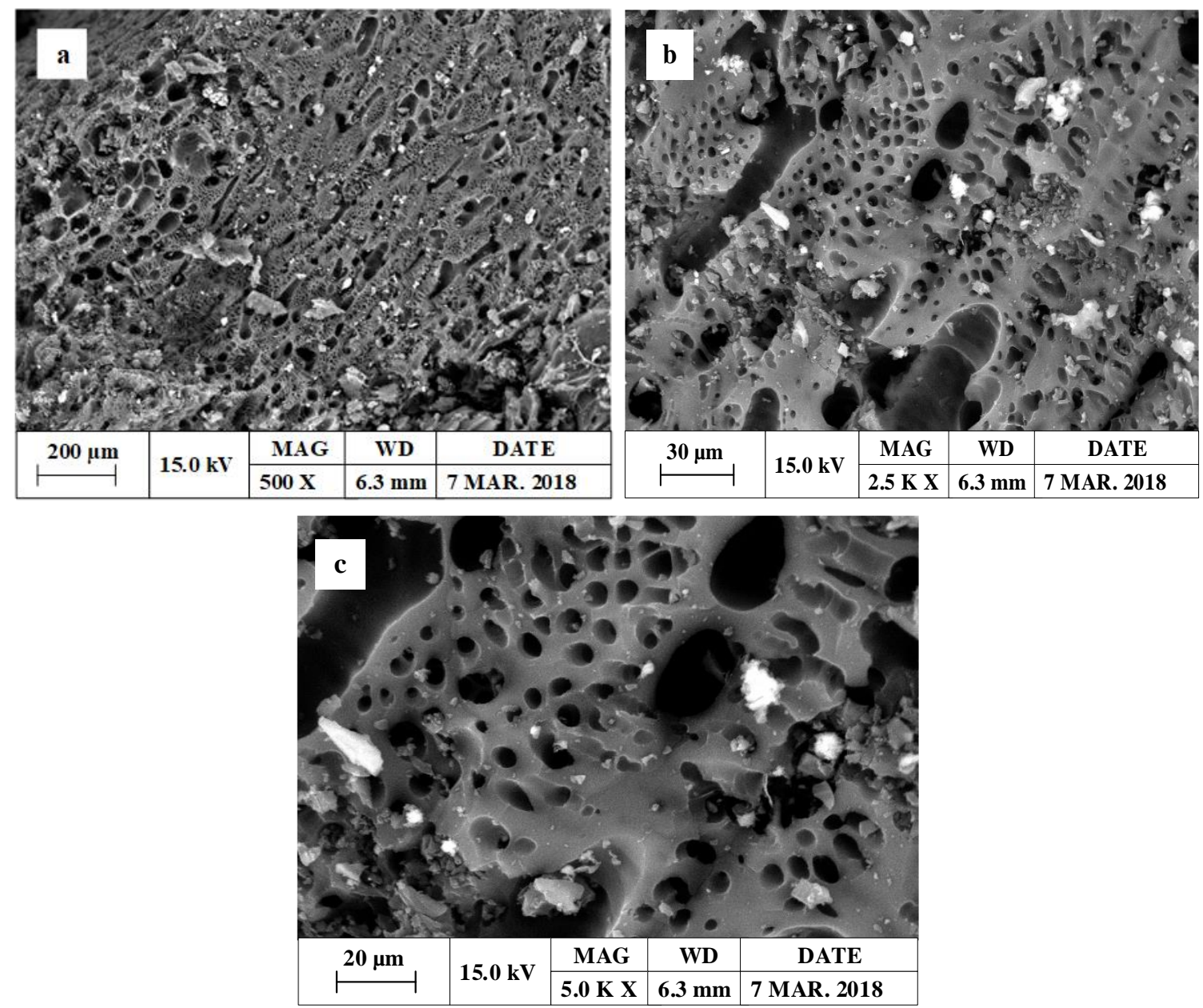

Figure 3. The images of GAC: (a) SEM images of 500× magnification (b) $2500 \times$ magnification (c) $5000 \times$ magnification.

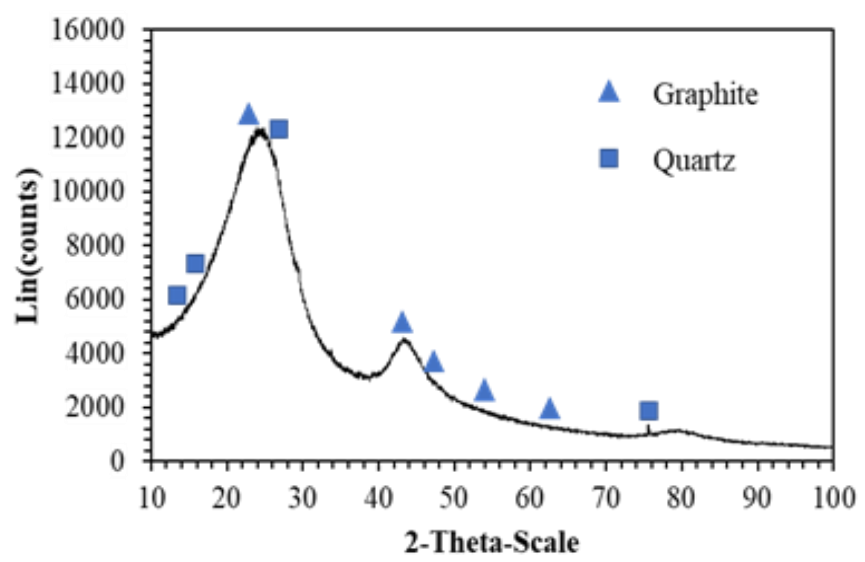

Figure 4. X-ray diffraction patterns of GAC.

The FTIR spectra analysis was carried out over the range from 600 to $4000 \mathrm{~cm}^{-1}$ (Figure 5). The bands at 1,$645 ; 1,430$; and $1,030 \mathrm{~cm}^{-1}$ indicative of $\mathrm{C}=\mathrm{O}$ stretch; $\mathrm{C}-\mathrm{O}$ stretch; and $\mathrm{C}-$ $\mathrm{OH}$ stretch [25]. After the adsorption of $\mathrm{NH}_{4}^{+}$, the band at $1,062 \mathrm{~cm}^{-1}$ corresponding to $\mathrm{C}-\mathrm{O}$ stretching was detected and would be caused by the adsorption of $\mathrm{NH}_{4}{ }^{+}$attached on the surface of GAC [27] while the band at $2,359 \mathrm{~cm}^{-1}$ could be assigned as $\mathrm{N}-\mathrm{H}$ group [28, 29]. The vibration at a wavelength range of 3,400 to $3,700 \mathrm{~cm}^{-1}$ indicates the presence of $\mathrm{O}-\mathrm{H}$ groups [30]. 


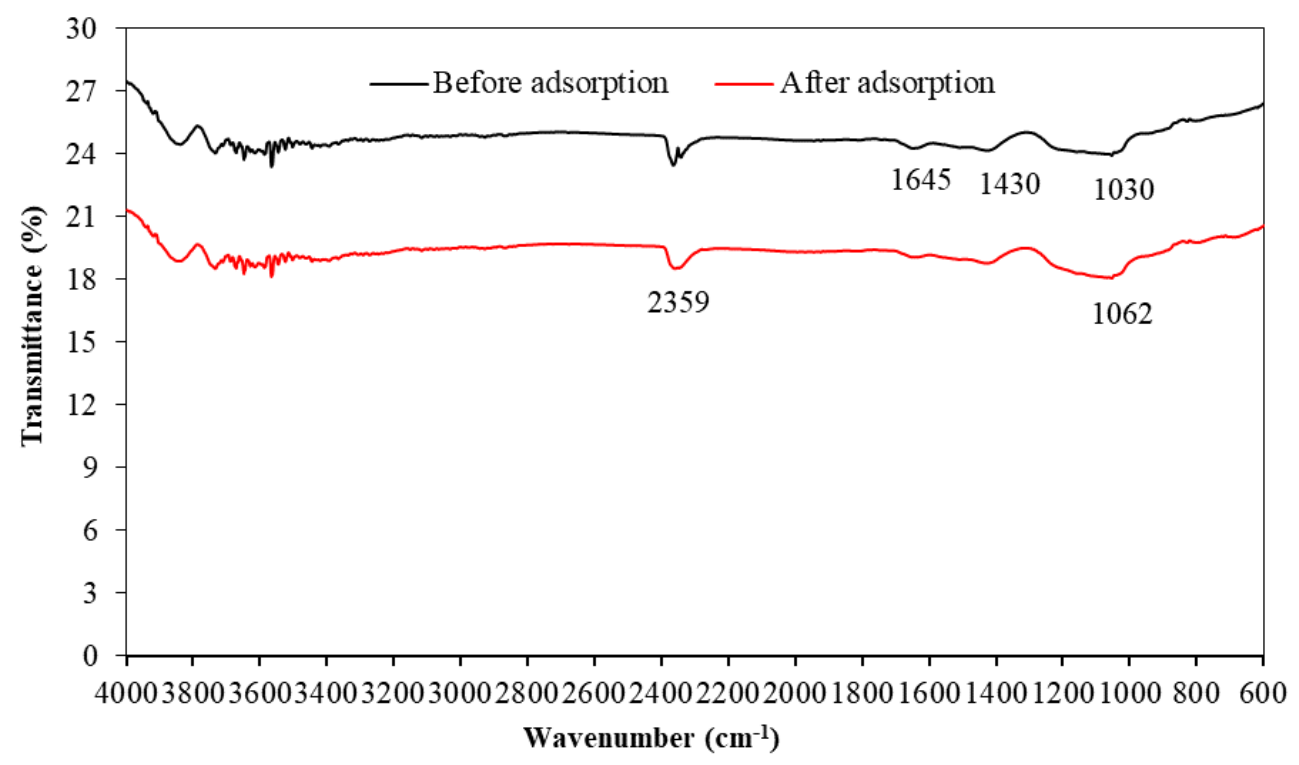

Figure 5. The FTIR spectra of GAC of before and after $\mathrm{NH}_{4}{ }^{+}$adsorption.

\subsection{Adsorption of $\mathrm{NH}_{4}^{+}$from a synthetic solution onto the GAC.}

Figure 6 shows the variations of $E$ pursuant to $t$ for the removal of $\mathrm{NH}_{4}{ }^{+}$using GAC. The use of GAC to adsorb $\mathrm{NH}_{4}{ }^{+}$could be favorable because the acidic functional groups of carboxylic, phenolic, and hydroxyl presented at the surface of GAC having negative charges could be more favorable to react with $\mathrm{NH}_{4}{ }^{+}$ions from synthetic solution to form the COO$\left(\mathrm{NH}_{4}\right)^{+}$complexes [31]. The efficiency of $\mathrm{NH}_{4}{ }^{+}$removal can reach approximately $20.1,50.1$, and $70.4 \%$ for the removal of $\mathrm{NH}_{4}{ }^{+}$after a contact time of $120 \mathrm{~h}$ with the amounts of GAC used to run the experiments were 4,12 , and $20 \mathrm{~g}$, respectively. The $E$ value to adsorb $\mathrm{NH}_{4}{ }^{+}$onto GAC rapidly increases over a time period of $24 \mathrm{~h}$ and then slowly increases to reach equilibrium (Figure 6). The rapid adsorption may be due to the availability of a high number of free active sites of the acidic functional groups present on the surface of the GAC that may have a high capability to adsorb $\mathrm{NH}_{4}{ }^{+}$ions from synthetic solution [32]. Subsequently, the rate of $\mathrm{NH}_{4}{ }^{+}$ adsorption is slow, which could be due to the abundance of active sites on the GAC that have been covered by $\mathrm{NH}_{4}^{+}$; the adsorption equilibrium can be then achieved after $90 \mathrm{~h}$ (Figure 6).

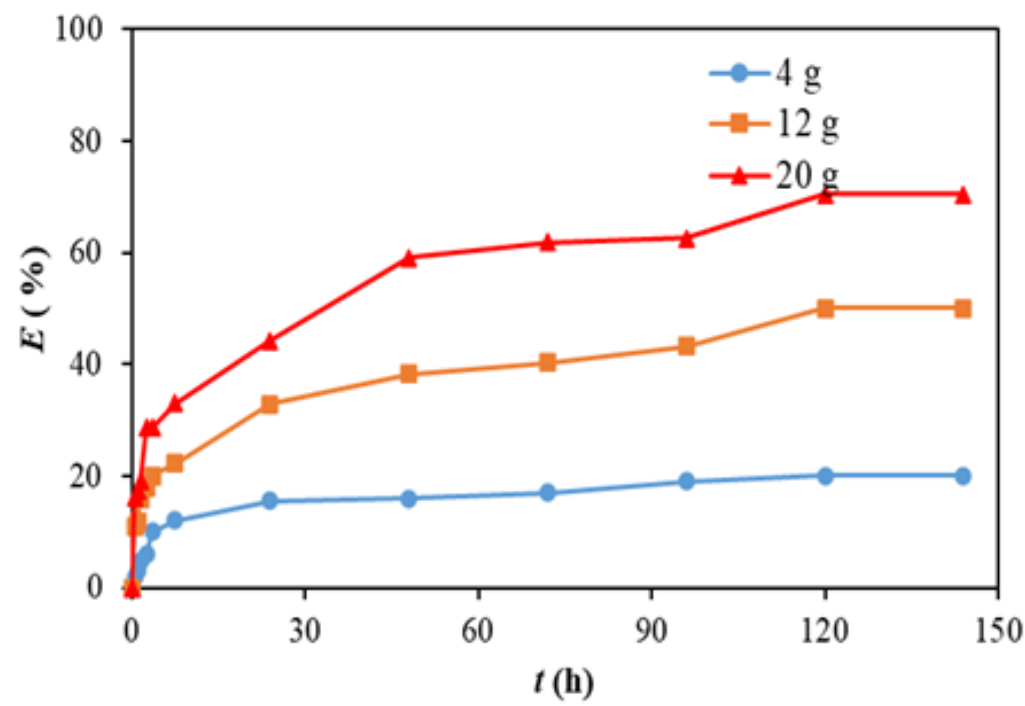

Figure 6. The efficiency of $\mathrm{NH}_{4}{ }^{+}$removal from synthetic solution. 
The plots of $E$ pursuant $m$ and $q$ pursuant $\mathrm{m}$ for the adsorption of $\mathrm{NH}_{4}{ }^{+}$from a synthetic solution onto GAC are shown in Figure 7. When the value of $m$ increasing from 4 to $20 \mathrm{~g}$, the value of $E$ gradually increases from 20.1 to $70.4 \%$, but $q$ gradually decreases from 0.101 to $0.070 \mathrm{mg} \mathrm{g}^{-1}$. More adsorbent used in a batch experiment could have more active sites available to attract $\mathrm{NH}_{4}{ }^{+}$from a synthetic solution, and thus the $E$ increases [33]. The $q$ value decreases with an increasing amount of the GAC because the use of more GAC to adsorb $\mathrm{NH}_{4}^{+}$from synthetic solution could have more unoccupied active sites, and thus the $q$ reduces [34-36].

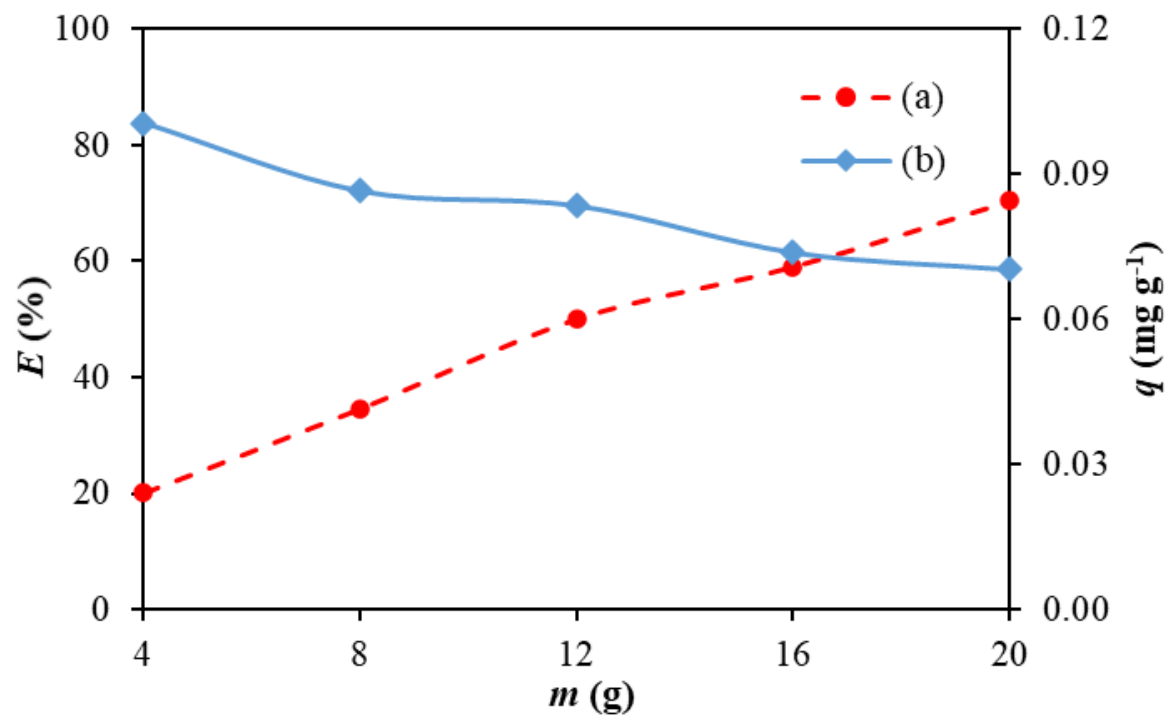

Figure 7. Relationship of: (a) $E$ versus $m$ and (b) $q$ versus $m$ for the $\mathrm{NH}_{4}{ }^{+}$adsorption onto GAC.

\subsection{Adsorption kinetics of $\mathrm{NH}_{4}{ }^{+}$onto the GAC.}

The $F_{\mathrm{e}}$ value can be calculated according to the following equation [37]. The most appropriate model, either PFO or PSO should have the smallest error function $\left(F_{\mathrm{e}}\right)$ value and the highest correlation coefficient $\left(R^{2}\right)$ value.

$$
F_{e}=\sqrt{\left(\frac{1}{n-p}\right) \sum_{i}^{n}\left(q_{t(\exp )}-q_{t(\text { theo })}\right)^{2}}
$$

where $p$ and $n$ are the numbers of kinetic parameters and measurements, respectively, $q_{t(\exp )}$ is the experimental $q$ value $\left(\mathrm{mg} \mathrm{g}^{-1}\right)$, and $q_{t(\text { theo })}$ is the theoretical $q$ value $\left(\mathrm{mg} \mathrm{g}^{-1}\right.$ ).

The linear regression analysis of the kinetic models for $\mathrm{NH}_{4}{ }^{+}$is shown in Figure 8. The $\left(R^{2}>0.986\right)$ for PSO model was higher than that $\left(R^{2}>0.908\right)$ for PFO model, as shown in Table 3. This study verifies that PSO model could be more suitable for the adsorption kinetic of $\mathrm{NH}_{4}{ }^{+}$onto GAC compared to PFO model due to the lower value of $F_{e}$ and the higher value of $R^{2}$ have been evaluated (Table 3). According to the results of this study, the adsorption between GAC and $\mathrm{NH}_{4}{ }^{+}$can be categorized as chemical adsorption because the adsorption process involving valency forces through sharing or exchange of electrons between the acidic functional groups and $\mathrm{NH}_{4}{ }^{+}$ions $[13,38]$. The value of $k^{2}$ increases from 0.025 to 0.028 and to $0.036 \mathrm{~g} \mathrm{mg}_{-}{ }^{1} \mathrm{~min}^{-1}$ with an increasing amount of the GAC from 4 to 12 and to $20 \mathrm{~g}$, meaning that the value of $k^{2}$ is positively correlated with the value of $m$ and thus, the rate of $\mathrm{NH}_{4}{ }^{+}$ adsorption onto GAC can be escalated by increasing the GAC dosage [16, 39]. 
Table 3. The kinetic parameters for PFO and PSO models.

\begin{tabular}{|c|c|c|c|c|c|c|}
\hline \multirow[b]{2}{*}{ Sample } & \multirow{2}{*}{$\frac{\text { Amount }}{(\mathrm{g})}$} & \multicolumn{3}{|c|}{ PFO model } & \multirow[b]{2}{*}{$F_{\mathrm{e}}$} & \multirow[b]{2}{*}{$q_{\mathrm{e}}(\exp )$} \\
\hline & & $q_{\mathrm{e}}($ theo $)$ & $k_{1}$ & $R^{2}$ & & \\
\hline & & $\left(\mathrm{mg} \mathrm{g}^{-1}\right)$ & $\left(\mathrm{min}^{-1}\right)$ & & & $\left(\mathrm{mg} \mathrm{g}^{-1}\right)$ \\
\hline \multirow[t]{4}{*}{ Synthetic solution } & 4 & 0.068 & 0.0004 & 0.908 & 0.037 & 0.101 \\
\hline & 12 & 0.056 & 0.0003 & 0.954 & 0.031 & 0.084 \\
\hline & 20 & 0.047 & 0.0004 & 0.939 & 0.025 & 0.070 \\
\hline & Amount & \multicolumn{3}{|c|}{ PSO model } & & \\
\hline \multirow[t]{2}{*}{ Sample } & (g) & $q_{\mathrm{e}}($ theo $)$ & $k_{2}$ & $R^{2}$ & $F_{\mathrm{e}}$ & $q_{\mathrm{e}}(\exp )$ \\
\hline & & $\left(\mathrm{mg} \mathrm{g}^{-1}\right)$ & $\left(\mathrm{g} \mathrm{mg}^{-1} \mathrm{~min}^{-1}\right)$ & & & $\left(\mathrm{mg} \mathrm{g}^{-1}\right)$ \\
\hline \multirow[t]{3}{*}{ Synthetic solution } & 4 & 0.103 & 0.025 & 0.994 & 0.007 & 0.101 \\
\hline & 12 & 0.083 & 0.028 & 0.986 & 0.019 & 0.084 \\
\hline & 20 & 0.071 & 0.036 & 0.992 & 0.007 & 0.070 \\
\hline
\end{tabular}
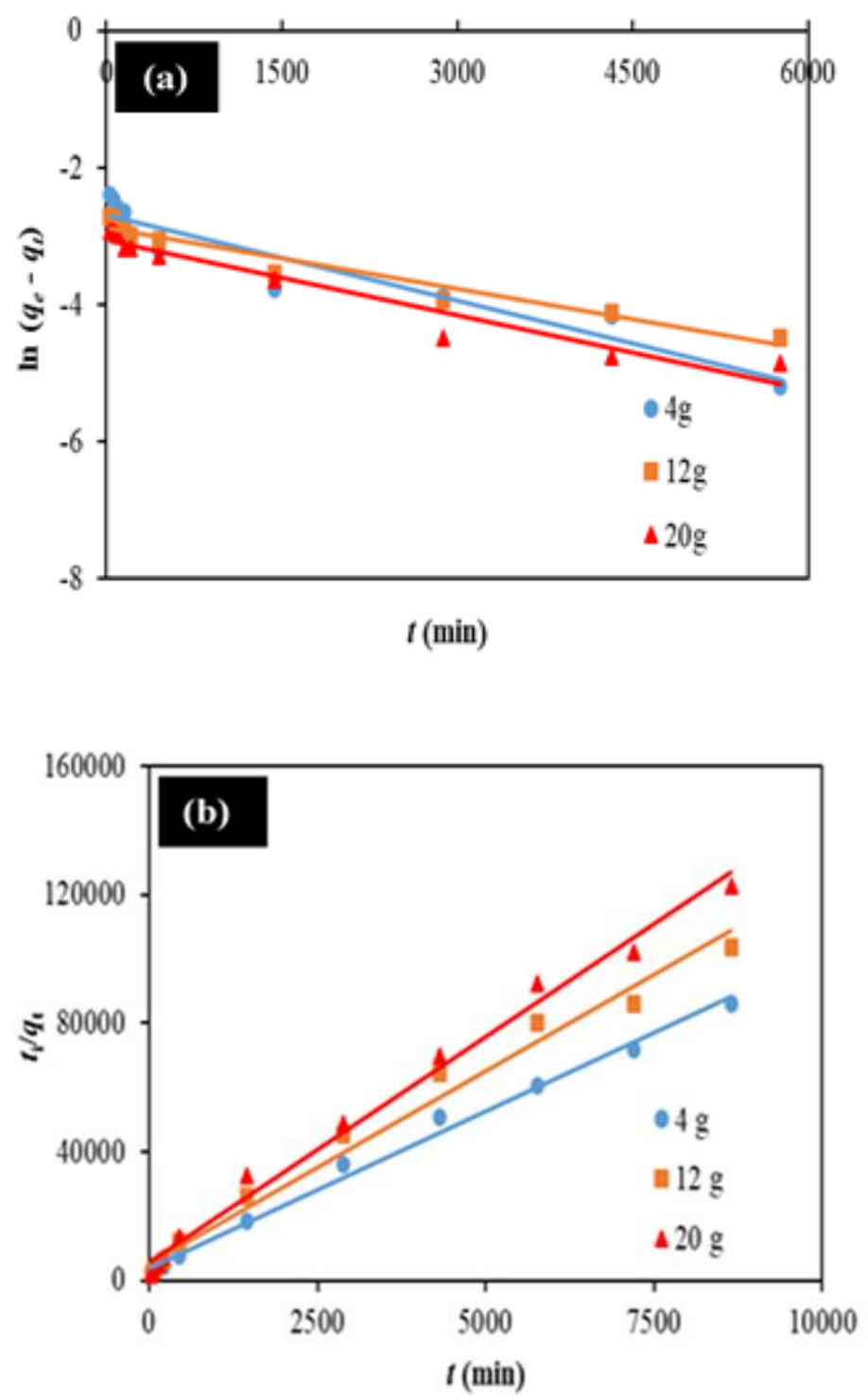

Figure 8. Experimental data of $\mathrm{NH}_{4}{ }^{+}$adsorption onto GAC fitted to linear forms (a) PFO model and (b) PSO model.

\subsection{Adsorption isotherms of $\mathrm{NH}_{4}{ }^{+}$onto the GAC.}

The Freundlich model (Figure 9a) and Langmuir model (Figure 9b) were used to analyzing the isotherms adsorption data. Table 4 shows the values of the isotherm parameters. This study found that the experimental data were best described by the Freundlich isotherm model $\left(R^{2}=0.9362\right)$ compared to the Langmuir isotherm model $\left(R^{2}=0.9023\right)$ as depicted in 
Table 4. The adsorption of $\mathrm{NH}_{4}{ }^{+}$occurred on the heterogeneous site of GAC progression with multilayer adsorption. The surfaces of the GAC are heterogeneous, and the sorption of $\mathrm{NH}_{4}^{+}$ onto GAC occurs in the form of multilayers $[6,40]$. The $n$ value of 2.80 was verified (Table 4). The $n$ value greater than one indicates favorable adsorption; active sites with the highest binding energies would be used first for less heterogeneous surfaces and then pursued by weaker sites for more heterogeneous surfaces [41-43].
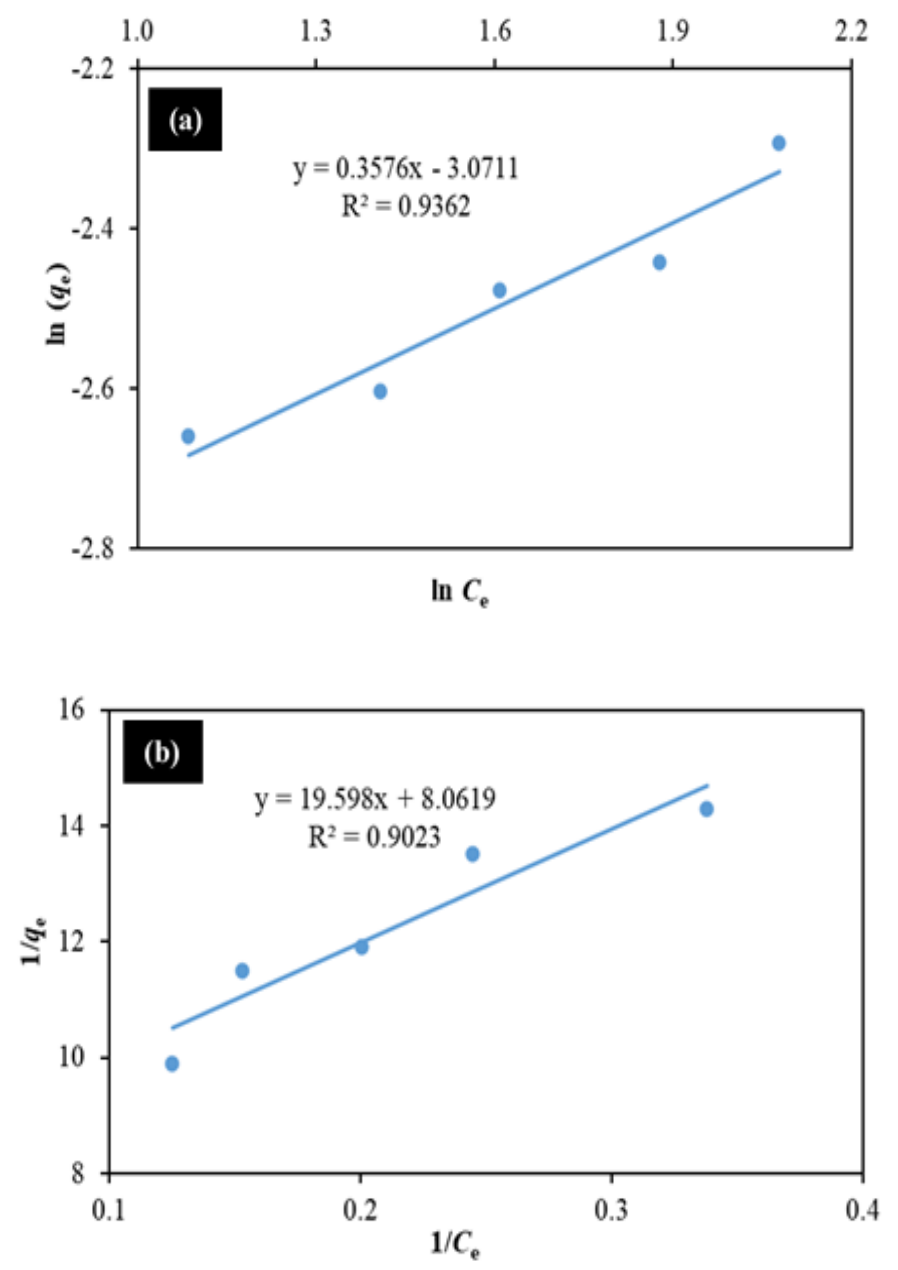

Figure 9. Experimental data of $\mathrm{NH}_{4}{ }^{+}$adsorption onto GAC fitted to (a) Freundlich model and (b) Langmuir model.

Table 4. The isotherm parameters for Freundlich and Langmuir models.

\begin{tabular}{|c|c|c|c|c|c|c|}
\hline & \multicolumn{3}{|c|}{ Freundlich model } & \multicolumn{3}{|c|}{ Langmuir model } \\
\hline Sample & $n$ & $K_{F}$ & $R^{2}$ & $q_{\max }$ & $K_{\mathrm{L}}$ & $R^{2}$ \\
\hline & & $\left(\mathrm{mg} \mathrm{g}^{-1}\right)$ & & $\left(\mathrm{mg} \mathrm{g}^{-1}\right)$ & $\left(\mathrm{L} \mathrm{mg}^{-1}\right)$ & \\
\hline Synthetic solution & 2.80 & 0.046 & 0.9362 & 0.124 & 0.411 & 0.9023 \\
\hline
\end{tabular}

3.10. Application of Freundlich isotherm to estimate E or q.

The Freundlich and Langmuir isotherm models in Eq. (3) and Eq. (4) were used to analyze the isotherms adsorption data, which is depicted in Figure 9. The results show that the Freundlich model (Figure 9a) could be more suitable to explain the experimental adsorption data compared to the Langmuir model (Figure 9b). The isotherm parameters $K_{\mathrm{F}}$ and $n$ for the Freundlich isotherm model are listed in Table 4.

The value of $E$ for any set of experimental conditions can be estimated when the Freundlich parameters $K_{\mathrm{F}}$ and $n$ were identified. Eq. (9) with Eq. (10) were used to obtain the 
value of $E$ predicted as a function of the initial concentration of $\mathrm{NH}_{4}{ }^{+}$solution with different amount of the adsorbent from 4 to $20 \mathrm{~g}$. The predicted data were compared to the experimental data for validation (Table 5 and 6). When $C_{\mathrm{i}}=10 \mathrm{mg} \mathrm{L}^{-1}$ for the synthetic solution and $m=4$, 12 , and $20 \mathrm{~g}$ for GAC in $0.2 \mathrm{~L}, E$ were predicted to be $19.4,49.3$, and $68.9 \%$ (Table 5). The experimental data values were $20.1,50.1$, and $70.4 \%$, and thus, the prediction errors were 3.6, 1.6 , and $2.1 \%$, respectively. These findings show that when constants (i.e., $K_{\mathrm{F}}$ and $n$ ) in Eq. (3) were evaluated with an experimental set under specific conditions, the $E$ in Eq. (10) can be predicted without significant error by using the model.

Furthermore, model verification was conducted to determine the required amount of adsorbent (Table 6) by using Eq. (11). In addition, when predicted $m$ and $E$ were obtained, $q$ can be estimated by using Eq. (12). When $C_{\mathrm{i}}=10 \mathrm{mg} \mathrm{L}^{-1}$ for the synthetic solution and desired $E=21.0,52.8$, and $72.5 \%$, the required $m$ was predicted to be around $4.4,13.2$, and $22.0 \mathrm{~g} \mathrm{~L}^{-1}$ and thus, the prediction errors were $9.1,9.9$, and $9.8 \%$, respectively. The adsorption capacities were predicted to be $0.10,0.08$, and $0.07 \mathrm{mg} \mathrm{g}^{-1}$ with an increasing amount of the GAC from 4.4 to 13.2 to $22.0 \mathrm{~g}$, and the prediction errors were $4.3,4.1$, and $6.2 \%$, respectively. These findings show that the $m$ required to eliminate pollutant/solute at the desired $E$ can be predicted.

Table 5. Comparison of $E$ experimental and $E$ predicted.

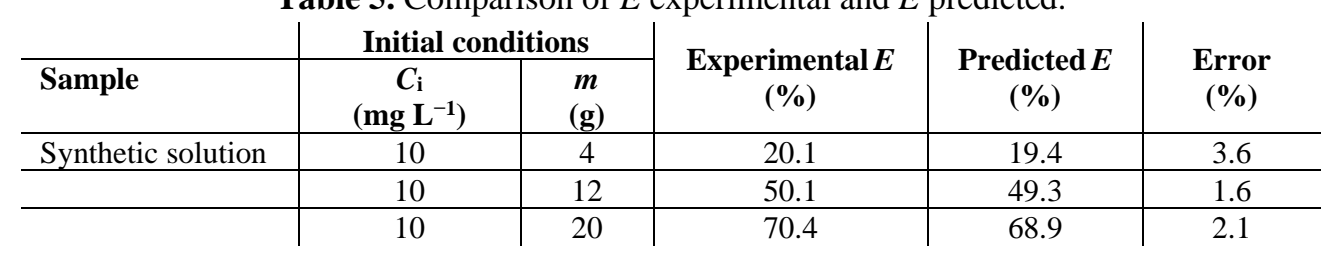

Table 6. Comparison of $m$ experimental and $m$ predicted.

\begin{tabular}{|c|c|c|c|c|c|c|c|}
\hline \multirow[b]{3}{*}{ Sample } & \multirow{2}{*}{\multicolumn{2}{|c|}{ Initial conditions }} & \multirow[b]{3}{*}{$\underset{(\mathrm{g})}{\text { Experimental } m}$} & \multirow[b]{3}{*}{$\begin{array}{c}\text { Predicted } m \\
(\mathrm{~g})\end{array}$} & & & \\
\hline & & & & & \multirow[b]{2}{*}{$\begin{array}{c}\text { Error } \\
(\%)\end{array}$} & \multirow[b]{2}{*}{$\begin{array}{l}\text { Predicted } q \\
\quad\left(\mathrm{mg} \mathrm{g}^{-1}\right)\end{array}$} & \multirow[b]{2}{*}{$\begin{array}{c}\text { Error } \\
(\%)\end{array}$} \\
\hline & $\begin{array}{c}C_{\mathrm{i}} \\
\left(\mathrm{mg} \mathrm{L}^{-1}\right)\end{array}$ & $\begin{array}{c}\text { Desired } E \\
(\%)\end{array}$ & & & & & \\
\hline \multirow{3}{*}{ Synthetic solution } & 10 & 21.0 & 4.0 & 4.4 & 9.1 & 0.10 & 4.3 \\
\hline & 10 & 52.8 & 12.0 & 13.2 & 9.9 & 0.08 & 4.1 \\
\hline & 10 & 72.5 & 20.0 & 22.0 & 9.8 & 0.07 & 6.2 \\
\hline
\end{tabular}

3.10.1. Practical application of the Freundlich isotherms.

The result of Figure 10 was generated by plotting $E$ against $m$ and $q$ against $m$ with the initial synthetic solution with a concentration of $10 \mathrm{mg} \mathrm{L}^{-1}$. This figure illustrates that when desired $E=72.5 \%$ at $C_{\mathrm{i}}=10 \mathrm{mg} \mathrm{L}^{-1}, m$ value of $22 \mathrm{~g}$ should be supplied in $1 \mathrm{~L}$ solution and thus $q=0.07 \mathrm{mg} \mathrm{g}^{-1}$ (points A and B in Figure 10), meaning that $22 \mathrm{~g}$ of GAC should be used to eliminate $72.5 \%$ of $\mathrm{NH}_{4}{ }^{+}$from $10 \mathrm{mg} \mathrm{L}^{-1}$ synthetic solution in a $1 \mathrm{~L}$ batch adsorption reactor.

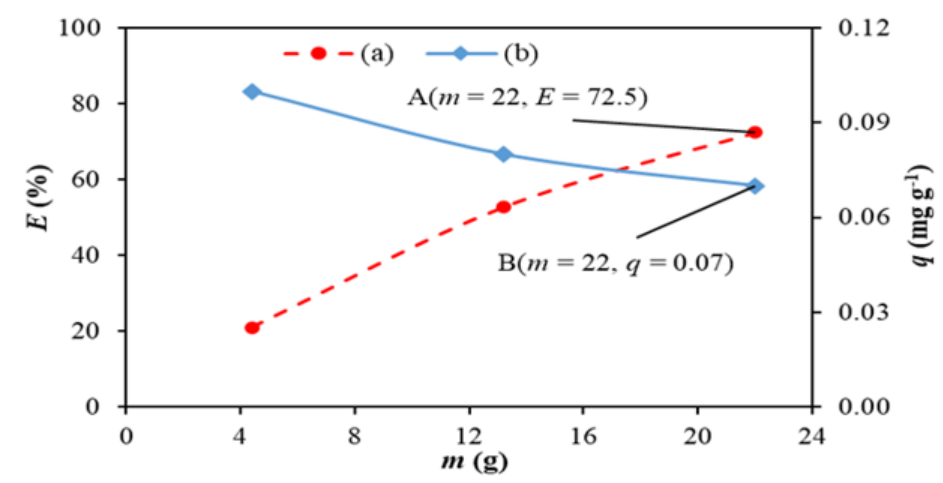

Figure 10. Relationship of: (a) $E$ pursuant $m$ and (b) $q$ pursuant $m$ for the adsorption of $\mathrm{NH}_{4}{ }^{+}$from synthetic solution onto GAC. 


\section{Conclusions}

In this research, the adsorption of $\mathrm{NH}_{4}^{+}$onto $\mathrm{GAC}$ from synthetic solution was best described by the Freundlich model, implying that the adsorption process would occur as a multilayer. The result findings can help to solve the excessive amounts of $\mathrm{NH}_{4}{ }^{+}$problem by using GAC as adsorbent and thus potentially improve environmental quality. Moreover, the isotherm model with mass balance permits estimation of the $m$ needed for the desired $E$ at an initial solute concentration, indicating that this model is practical in the adsorption process used for pollutant removal from water.

\section{Funding}

We thank the Ministry of Higher Education for financial support (Fundamental Research Grant Scheme: Vote Number: 4F956)

\section{Acknowledgments}

We thank the Centre for Environmental Sustainability and Water Security (IPASA) for laboratory facilities.

\section{Conflicts of Interest}

The authors declare no conflict of interest.

\section{References}

1. Huang, J.; Kankanamge, N.R.; Chow, C.; Welsh, D.T.; Li, T.; Teasdale, P.R. Removing ammonium from water and wastewater using cost-effective adsorbents: A review. Journal of Environmental Sciences (China) 2018, 63, 174-197, https://doi.org/10.1016/j.jes.2017.09.009.

2. Zhou, Y.; Wang, L.; Zhou, Y.; Mao, X.Z. Eutrophication control strategies for highly anthropogenic influenced coastal waters. Science of the Total Environment 2020, 705, https://doi.org/10.1016/j.scitotenv.2019.135760.

3. Li, R.; Wang, J.J.; Zhou, B.; Awasthi, M.K.; Ali, A.; Zhang, Z.; Mahar, A. Enhancing phosphate adsorption by $\mathrm{Mg} / \mathrm{Al}$ layered double hydroxide functionalized biochar with different $\mathrm{Mg} / \mathrm{Al}$ ratios. Science of the Total Environment 2016, 559, 121-129, http://dx.doi.org/10.1016/j.scitotenv.2016.03.151.

4. Le Moal, M.; Gascuel-Odoux, C.; Ménesguen, A.; Souchon, Y.; Étrillard, C.; Levain, A.; Pinay, G. Eutrophication: A new wine in an old bottle? Science of the Total Environment 2019, 651, 1-11, https://doi.org/10.1016/j.scitotenv.2018.09.139.

5. Oakley, S.M.; Gold, A.J.; Oczkowski, A.J. Nitrogen control through decentralized wastewater treatment: Process performance and alternative management strategies. Ecological Engineering 2010, 36, 1520-1531, http://dx.doi.org/10.1016/j.ecoleng.2010.04.030.

6. Deng, Y.; Huang, S.; Dong, C.; Meng, Z.; Wang, X. Competitive adsorption behaviour and mechanisms of cadmium, nickel and ammonium from aqueous solution by fresh and ageing rice straw biochars. Bioresource Technology 2020, 303, https://doi.org/10.1016/j.biortech.2020.122853.

7. Sarvajith, M.; Kiran Kumar Reddy, G.; Nancharaiah, Y.V. Aerobic granular sludge for high-strength ammonium wastewater treatment: Effect of $\mathrm{COD} / \mathrm{N}$ ratios, long-term stability and nitrogen removal pathways. Bioresource Technology 2020, 306, https://doi.org/10.1016/j.biortech.2020.123150.

8. Zhang, P.; Zeng, X.; Wen, X.; Yang, C.; Ouyang, S.; Li, P.; Frost, R.L. Insights into efficient removal and mechanism for ammonium from aqueous solution on tricalcium aluminate. Chemical Engineering Journal 2019, 366, 11-20, https://doi.org/10.1016/j.cej.2019.02.010.

9. Pavani, K.V.; Srujana, N.; Preethi, G.; Swati, T. Green synthesis of copper nanoparticles using extract of Dicliptera Roxburghiana, their characterization and photocatalytic activity against methylene blue degradation. Letters in Applied NanoBioScience 2020, 9, 897-901.

10. Nagoya, S.; Nakamichi, S.; Kawase, Y. Mechanisms of phosphate removal from aqueous solution by zerovalent iron: A novel kinetic model for electrostatic adsorption, surface complexation and precipitation of phosphate under oxic conditions. Separation and Purification Technology 2019, 218, 120-129, http://dx.doi.org/10.1016/j.seppur.2019.02.042.

11. Lalley, J.; Han, C.; Li, X.; Dionysiou, D.D.; Nadagouda, M.N. Phosphate adsorption using modified iron 
oxide-based sorbents in lake water: Kinetics, equilibrium, and columntests. Chemical Engineering Journal 2016, 284, 1386-1396, http://dx.doi.org/10.1016/j.cej.2015.08.114.

12. Worch, E. Adsorption Technology in Water Treatment: Fundamentals, Processes, and Modeling. Walter de Gruyter GmbH \& Co. KG: Boston, Germany, 2012; pp. 1-11, https://doi.org/10.1515/9783110240238.

13. Fan, R.; Chen, C.L.; Lin, J.Y.; Tzeng, J.H.; Huang, C.P.; Dong, C.; Huang, C.P. Adsorption characteristics of ammonium ion onto hydrous biochars in dilute aqueous solutions. Bioresource Technology 2019, 272, 465-472, https://doi.org/10.1016/j.biortech.2018.10.064.

14. Min, L.; Zhongsheng, Z.; Zhe, L.; Haitao, W. Removal of nitrogen and phosphorus pollutants from water by $\mathrm{FeCl}_{3}^{-}$impregnated biochar. Ecological Engineering https://doi.org/10.1016/j.ecoleng.2020.105792.

15. Hubadillah, S.K.; Othman, M.H.D.; Harun, Z.; Ismail, A.F.; Rahman, M.A.; Jaafar, J. A novel green ceramic hollow fiber membrane (CHFM) derived from rice husk ash as combined adsorbent-separator for efficient heavy metals removal. Ceramics International 2017, 43, 4716-4720, https://doi.org/10.1016/j.ceramint.2016.12.122.

16. Salim, N.A.A.; Abdullah, N.H.; Khairuddin, M.R.; Rudie Arman, M.A.Z.; Khamidun, M.H.; Fulazzaky, M.A.; Puteh, M.H. Adsorption of phosphate from aqueous solutions using waste mussel shell. MATEC Web of Conferences 2018, 250, https://doi.org/10.1051/matecconf/201825006013.

17. Wang, L.; Wang, X.; Jin, X.; Xu, J.; Zhang, H.; Yu, J.; Wang, L. Analysis of algae growth mechanism and water bloom prediction under the effect of multi-affecting factor. Saudi Journal of Biological Sciences 2017, 24, 556-562, https://doi.org/10.1016/j.sjbs.2017.01.026.

18. Rashidi Nodeh, H.; Sereshti, H.; Zamiri Afsharian, E.; Nouri, N. Enhanced removal of phosphate and nitrate ions from aqueous media using nanosized lanthanum hydrous doped on magnetic graphene nanocomposite. Journal of Environmental Management 2017, 197, 265-274, https://doi.org/10.1016/j.jenvman.2017.04.004.

19. Singh, N.B.; Nagpal, G.; Agrawal, S.; Rachna. Water purification by using Adsorbents: A Review. Environmental Technology and Innovation 2018, 11, 187-240, https://doi.org/10.1016/j.eti.2018.05.006.

20. Efome, J.E.; Rana, D.; Matsuura, T.; Lan, C.Q. Metal-organic frameworks supported on nanofibers to remove heavy metals. Journal of Materials Chemistry A 2018, 6, 4550-4555, https://doi.org/10.1039/c7ta10428f.

21. Salim, N.A.A.; Puteh, M.H.; Yusoff, A.R.M.; Abdullah, N.H.; Fulazzaky, M.A.; Rudie Arman, M.A.Z.; Zaini, M.A.A.; Khamidun, M.H.; Lazim, Z.M.; Nuid, M.; Ahmad, N.; Zainuddin, N.A. Adsorption isotherms and kinetics of phosphate on waste mussel shell. Malaysian Journal of Fundamental and Apllied Sciences 2020, 16, 393-399.

22. Chung, H.; Kim, W.; Park, J.; Cho, J.; Jeong, T.; Park, P. Application of Langmuir and Freundlich isotherms to predict adsorbate removal efficiency or required amount of adsorbent. Journal of Industrial and Engineering Chemistry 2015, 28, 241-246, https://doi.org/10.1016/j.jiec.2015.02.021.

23. American Public Health Association (APHA). Standard Methods for the Examination of Water and Wastewater. 21st ed., Springer, Washington DC, 2005.

24. Fan, Z.; Li, Z.; Sun, Q.; Cunha, E.; Kinloch, I.A.; Ren, H.; Young, R.J. Surface functionality analysis by Boehm titration of graphene nanoplatelets functionalized via a solvent-free cycloaddition reaction. Nanoscale Advances 2019, 1, 1432-1441, https://doi.org/10.1039/C8NA00280K.

25. Zeng, T.; Huang, H.; Kobayashi, N.; Li, J. Performance of an activated carbon-ammonia adsorption refrigeration system. Natural Resources 2017, 08, 611-631, https://doi.org/10.4236/nr.2017.810039.

26. Yuan, H.; Lu, T.; Huang, H.; Zhao, D.; Kobayashi, N.; Chen, Y. Influence of pyrolysis temperature on physical and chemical properties of biochar made from sewage sludge. Journal of Analytical and Applied Pyrolysis 2015, 112, 284-289, https://doi.org/10.1016/j.jaap.2015.01.010.

27. Chen, L.; Chen, X.L.; Zhou, C.H.; Yang, H.M.; Ji, S.F.; Tong, D.S.; Chu, M.Q. Environmental-friendly montmorillonite-biochar composites: Facile production and tunable adsorption-release of ammonium and phosphate. Journal of Cleaner Production 2017, 156, 648-659, https://doi.org/10.1016/j.jclepro.2017.04.050.

28. Basha, S.; Murthy, Z.V.P.; Jha, B. Sorption of Hg (II) onto Carica papaya: Experimental studies and design of batch sorber. Chemical Engineering Journal 2009, 147, 226-234, https://doi.org/10.1016/j.cej.2008.07.005.

29. Saha, P.D.; Chakraborty, S.; Chowdhury, S. Batch and continuous (fixed-bed column) biosorption of crystal violet by Artocarpus heterophyllus (jackfruit) leaf powder. Colloids and Surfaces B: Biointerfaces 2012, 92, 262-270, https://doi.org/10.1016/j.colsurfb.2011.11.057.

30. Li, R.; Wang, J.J.; Zhang, Z.; Awasthi, M.K.; Du, D.; Dang, P.; Wang, L. Recovery of phosphate and dissolved organic matter from aqueous solution using a novel $\mathrm{CaO}-\mathrm{MgO}$ hybrid carbon composite and its feasibility in phosphorus recycling. Science of the Total Environment 2018, 642, 526-536, https://doi.org/10.1016/j.scitotenv.2018.06.092.

31. Sumaraj; Xiong, Z.; Sarmah, A.K.; Padhye, L.P. Acidic surface functional groups control chemisorption of ammonium onto carbon materials in aqueous media. Science of the Total Environment 2020, 698, https://doi.org/10.1016/j.scitotenv.2019.134193.

32. Zhu, Y.; Kolar, P.; Shah, S.B.; Cheng, J.J.; Lim, P.K. Avocado seed-derived activated carbon for mitigation of aqueous ammonium. Industrial Crops and Products 2016, 92, 34-41, 
https://doi.org/10.1016/j.indcrop.2016.07.016.

33. Bagali, S.S.; Gowrishankar, B.S.; Roy, A.S. Optimization, kinetics, and equilibrium studies on the removal of lead(ii) from an aqueous solution using banana pseudostem as an adsorbent. Engineering 2017, 3, 409415, https://doi.org/10.1016/J.ENG.2017.03.024.

34. Cao, D.; Jin, X.; Gan, L.; Wang, T.; Chen, Z. Removal of phosphate using iron oxide nanoparticles synthesized by eucalyptus leaf extract in the presence of CTAB surfactant. Chemosphere 2016, 159, 23-31, https://doi.org/10.1016/j.chemosphere.2016.05.080.

35. Daud, Z.; Abubakar, M.H.; Kadir, A.A.; Abdul, A.A.; Awang, H.; Halim, A.A.; Marto, A. Batch study on $\mathrm{COD}$ and ammonia nitrogen removal using granular activated carbon and cockle shells. International Journal of Engineering 2017, 30, 937-944.

36. Zhai, L.; Bai, Z.; Zhu, Y.; Wang, B.; Luo, W. Fabrication of chitosan microspheres for efficient adsorption of methyl orange. Chinese Journal of Chemical Engineering 2018, 26, 657-666, https://doi.org/10.1016/j.cjche.2017.08.015.

37. Ribas, M.C.; Adebayo, M.A.; Prola, L.D.T.; Lima, E.C.; Cataluña, R.; Feris, L.A.; Calvete, T. Comparison of a homemade cocoa shell activated carbon with commercial activated carbon for the removal of reactive violet 5 dye from aqueous solutions. Chemical Engineering Journal 2014, 248, 315-326, https://doi.org/10.1016/j.cej.2014.03.054.

38. Hu, X.; Zhang, X.; Ngo, H.H.; Guo, W.; Wen, H.; Li, C.; Ma, C. Comparison study on the ammonium adsorption of the biochars derived from different kinds of fruit peel. Science of the Total Environment 2020, 707, https://doi.org/10.1016/j.scitotenv.2019.135544.

39. Huang, W.Y.; Zhu, R.H.; He, F.; Li, D.; Zhu, Y.; Zhang, Y.M. Enhanced phosphate removal from aqueous solution by ferric-modified laterites: Equilibrium, kinetics and thermodynamic studies. Chemical Engineering Journal 2013, 228, 679-687, https://doi.org/10.1016/j.cej.2013.05.036.

40. Wang, L.; Chen, Z.; Wen, H.; Cai, Z.; He, C.; Wang, Z.; Yan, W. Microwave assisted modification of activated carbons by organic acid ammoniums activation for enhanced adsorption of acid red 18. Powder Technology 2018, 323, 230-237, https://doi.org/10.1016/j.powtec.2017.10.021.

41. Marañón, E.; Ulmanu, M.; Fernández, Y.; Anger, I.; Castrillón, L. Removal of ammonium from aqueous solutions with volcanic tuff. Journal of Hazardous Materials 2006, 137, 1402-1409, https://doi.org/10.1016/j.jhazmat.2006.03.069.

42. Kaya, E.M.Ö.; Özcan, A.S.; Gök, Ö.; Özcan, A. Adsorption kinetics and isotherm parameters of naphthalene onto natural- and chemically modified bentonite from aqueous solutions. Adsorption 2013, 19, 879-888, https://doi.org/10.1007/s10450-013-9542-3.

43. Shi, M.; Wang, Z.; Zheng, Z. Effect of $\mathrm{Na}^{+}$impregnated activated carbon on the adsorption of $\mathrm{NH}_{4}{ }^{+}-\mathrm{N} \mathrm{from}^{-}$ aqueous solution. Journal of Environmental Sciences (China) 2013, 25, 1501-1510, https://doi.org/10.1016/S1001-0742(8)60227-7. 